CURRENT BIOCHEMISTRY

ISSN: $2355-7877$

Journal Homepage: http://biokimia.ipb.ac.id

Journal Email: current.biochemistry@ipb.ac.id

\title{
Detection of Subclinical Mastitis in Dairy Cows using California Mastitis Test and Udder Pathogen
}

\author{
Evi Nur Qolbaini ${ }^{*}$, I Made Artika ${ }^{1}$, Dodi Safari ${ }^{2}$ \\ ${ }^{1}$ Department of Biochemistry, Bogor Agricultural University (IPB), Bogor 16680, Indonesia \\ ${ }^{2}$ Eijkman Institute for Molecular Biology, Diponegoro street 69, Jakarta
}

Received: 26 June 2014; Accepted 23 July 2014

*Corresponding author: Evi Nur Qolbaini, S.Si; Department of Biochemistry, Agatis street, Animal Science building 5th floor, Bogor 16680; email: evinurqolbaini@yahoo.co.id

\section{ABSTRACT}

Subclinical mastitis is an infection of the udder devoid of clinical symptoms, bacteria are one of the causes behind this disease. In the present study, we investigated subclinical mastitis in dairy cows using the California mastitis test (CMT) and udder pathogens from KUNAK (Kawasan Usaha Peternak Sapi Perah) Cibungbulang, Bogor, West Java, Indonesia. We randomly collected 102 milk samples from dairy farms in different stalls. We found that 87 out of the 102 (86\%) milk samples were positive for CMT test with level +1 , level +2 , and level +3 were $22 \%, 45 \%$, and 33\% respectively. We also identified three different major bacterial groups: staphylococcus, streptococcus, and enterobacteria based on gram staining, oxidase test, and coagulase test. It can be concluded that the case of bovine subclinical mastitis in Kunak Bogor was very high and caused by various bacteria which infected cows

Keywords: mastitis, CMT, dairy cows

\section{INTRODUCTION}

Mastitis is an inflammation of the mammary gland and is a response to the injury caused by bacteria in the return to normal function. In the area of dairy farms, many cases of mastitis are caused by microorganisms that invade the udder and then multiply and produce toxins that are dangerous to the mammary gland (Jones 2009; Schroeder 2012). As a result of inflammation in the udder, Schroeder (2012) and Seegers et al. (2003) explain that it contributed to reductions in milk production and milk quality. The reduction of quality can be seen from levels of lactose, fat, minerals, and potassium. The changing of the milk's composition and quality can cause economic loss.

The changing of milk quality is caused by bacteria that multiply in the milk as milk is a good medium for bacterial growth. Based on research that conducted by Taponen et al. (2009) the types of microorganisms that cause inflammation in the udder are Staphylococcus 
aureus, Streptococcus uberis, Streptococcus dysgalactiae, Corynebacterium bovis, Staphilococcus aureus, Escherichia coli, Arcanobacterium pyogenes. Early examination to detect mastitis needs to be done to prevent and treat mastitis, especially for subclinical mastitis. In the case of subclinical mastitis, clinical symptoms are not visible around the udder, such as swelling, temperature rise, redness and pain when touched, but there is also a change in the milk composition (Hidayat et al. 2002).

The CMT test (California mastitis test) is one method to detect mastitis in low levels of abnormality (subclinical). This test is easy to implement and effective at detecting mastitis (Surjowardojo et al. 2008). CMT has a high sensitivity (over 90\%) for detecting mastitis according to Sudarwanto (1998). Therefore, CMT was used to detect subclinical mastitis in Kawasan Usaha Peternak Sapi Perah (KUNAK) in Cibungbulang, Bogor. The purpose of this research was to carry out a survey on the case of subclinical mastitis at KUNAK, Bogor and determine the type of bacteria infected by gram staining, catalase test and oxidase test.

\section{MATERIALS AND METHODS}

\section{CMT Test}

Samples were taken from different stalls in KUNAK Bogor as license by the Husbandry and Fishery Department in Cibinong, Bogor. The CMT test (California Mastitis Test) was used to detect subclinical mastitis in bovines. Sampling was carried out under sterile condition by cleaning the area of the udder using alcohol $70 \%$ and milked using gloves. The second and third milkings were collected on a paddle, and CMT reagent was added at a ratio of $1: 1$. The paddle turned slowly for 10-15 seconds. Samples with positive mastitis will form purple gel in solution on the basis of paddle (Surjowardojo et al. 2008). The mastitis Score was determined by the number $0,+1,+2$, and +3 (Barnum \& newbould 1961). Milk from bovines with positive subclinical mastitis was collected in a sterile tube and stored at $4^{\circ} \mathrm{C}$.

\section{Bacterial isolation and characterization}

As much as $10-15 \mu \mathrm{L}$ of milk samples were cultured in medium Blood Agar (BA) and Mac Conkey Agar (MCA), then incubated for 24-48 hours at temperature of $37^{\circ} \mathrm{C}$. The gram stain was used to determine the morphology of bacteria (Putri 2012). The oxidase and catalase tests were needed to identify more types of bacteria that have been previously observed under the microscope (Harley \& Prescott 2002; Marlina 2008).

\section{RESULTS}

The CMT test for early detection of the presence of mastitis is indicated by numbers $+1,+2$, and +3 . The numbers showed the

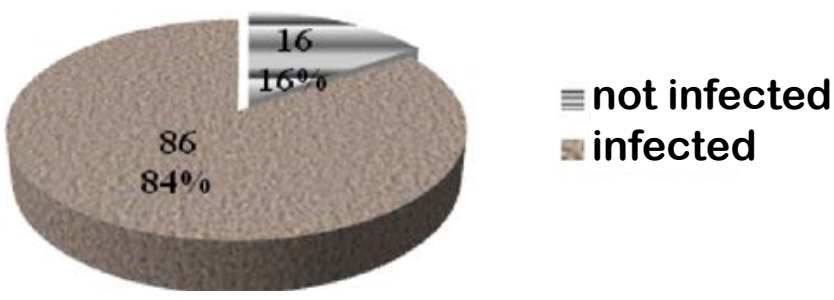

Figure 1 the precentage of cows infected with subclinical mastitis

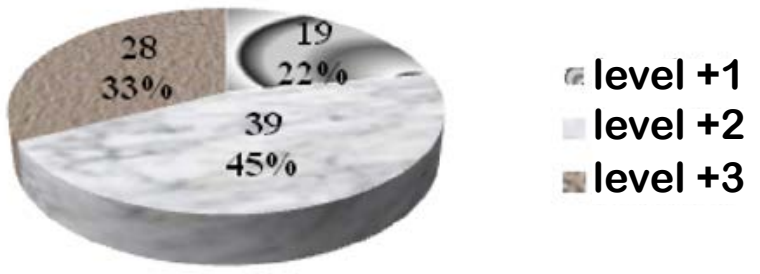

Figure 2 Infection rate of subclinical mastitis 
viscosity of gelatin that was formed (Barnum $\&$ Newbould 1961). The results of subclinical mastitis detection in KUNAK Bogor showed

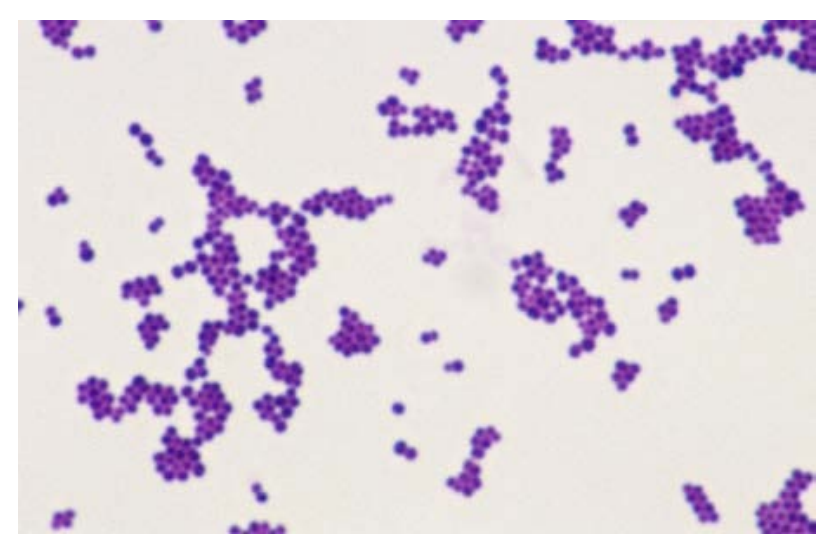

A

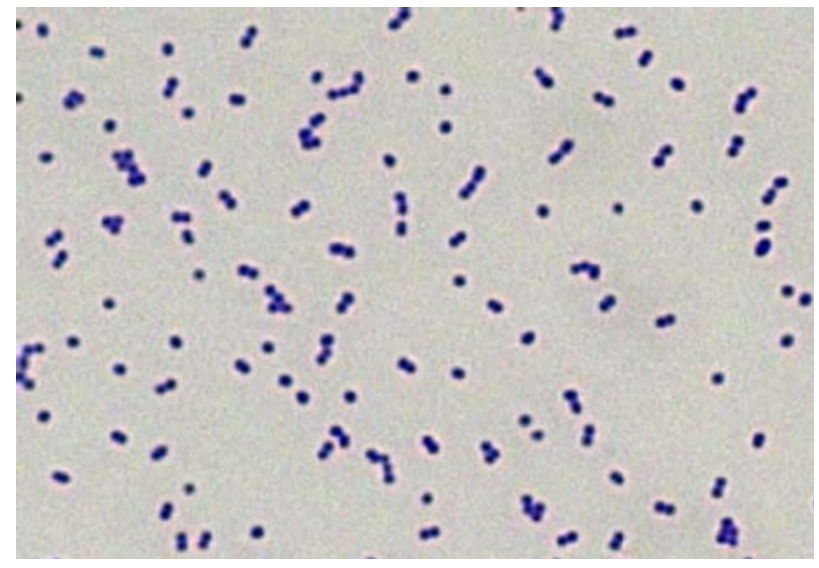

B

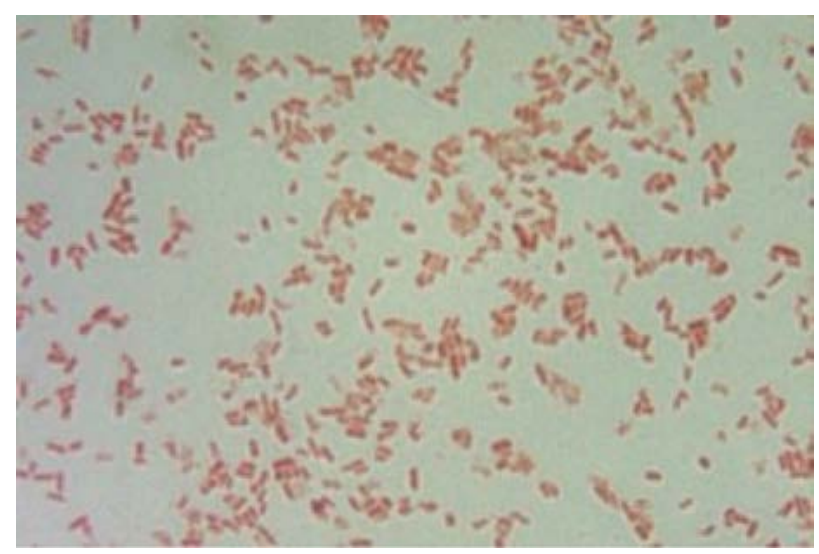

C

Figure 3 (A) Gram positive coccus, grape-like structures; (B) Gram positive coccus, chain-like structures; and (C) Gram negative bacillus, single colony that $84 \%$ or 86 out of 102 cows were infected with subclinical mastitis (Figure 1), 45\% of them was at level 2 , and $33 \%$ was at level 3 (Figure 2).

Examination of subclinical mastitis bacteria used 3 methods, namely Gram staining, the oxidase test, and the catalase test. The aim of Gram staining was to determine Gram positive or Gram negative bacteria, determine the bacterial morphology and charecteristic of bacterial colonies (Figure 3).

The oxidase test was used to determine the presence of cytochrome oxidase which can be found in certain microorganisms. While the catalase test was used to determine the presence of catalase enzyme that catalyze the breakdown of hydrogen peroxide $\left(\mathrm{H}_{2} \mathrm{O}_{2}\right)$ into $\mathrm{H}_{2} \mathrm{O}$ and $\mathrm{O}_{2}$ (Harley \& Prescott 2002). Based on the results of all tests, the bacteria that cause mastitis can be classified according to Figure 4 .

\section{DISCUSSION}

CMT is based on a reaction between the reagent which contains arylsulfonate with leukocytes in milk which were found in large numbers when infections occured, such as mastitis in bovines. The reaction between reagent and leukocyte forms a gelatinous milk. The viscosity of the gelatin indicates the number of leukocytes present in the milk and indicates the level of bacterial infection which is causing subclinical mastitis (Akers 2002). Acoording Blowey \& Edmonson (2010), when infection occurs in milk, PMNs (polymorphonuclear leucocytes) have higher activity than in the blood because of endotoxins released by bacteria that stimulate PMNs to be released to milk in large numbers. 


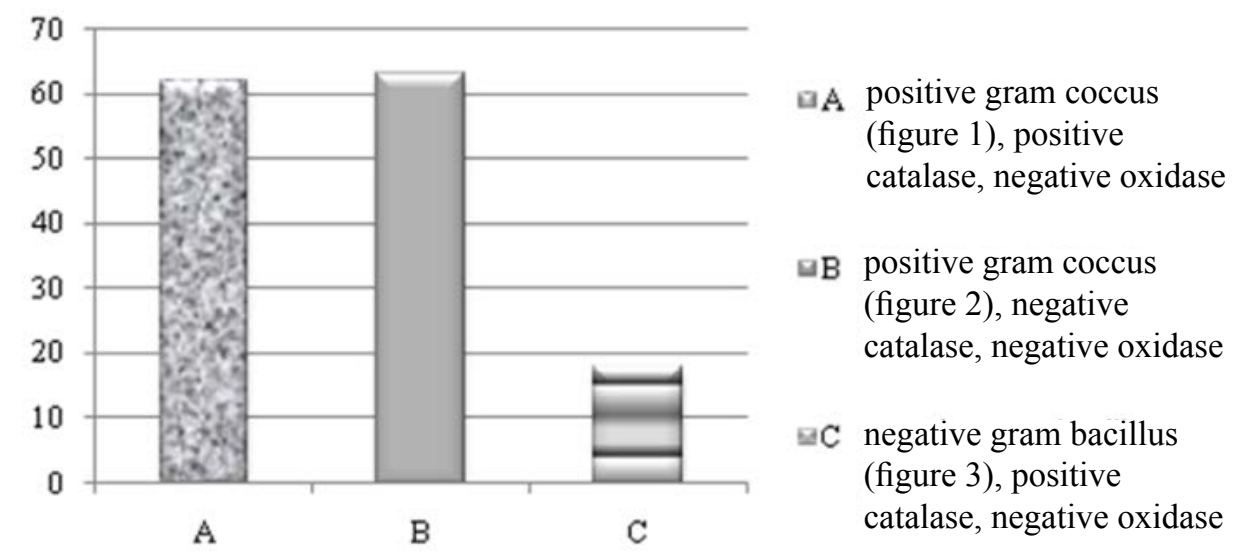

Figure 4 Clasifying of bovine subclinical mastitis bacteria

The infection rate of subclinical mastitiscausing bacteria in KUNAK Bogor was high. It was based on detection of subclinical mastitis using CMT that showed high precentages. In various prevalence studies, such as carried out in East Java, more than $80 \%$ of bovine mastitis cases were subclinical (Efendi 2013). According to Schroeder (2012) bovine udder was the main entrance for microorganisms during lactation, and the environment determined the type of bacteria that can multiply. Based on observations in KUNAK Bogor, cowshed environment supported the occurrence of mastitis, such as the condition of the cowshed was full of dung, making it damp and slippery, uncleaned udders, and the absence of a system dung waste disposal. Based on reseach of Zdanowicz (2002), 50-60\% cows spent their time in a cowshed and slept on the floor. Thi activity facilitated the movement of bacteria to the udder causing infection, because sanitation is one of factors that influence mastitis. The other factor that causes mastitis is the milking process. Based on observations in KUNAK Bogor, all breeders used hand for the milking process. An incorrect milking process can lead to infection on the udder. Good milking management involves pre-dipping and postdipping in sanitizing solution (Bewley $\mathrm{J}$ et al. 2012). Pre-dipping is to sanitize the udder before milking, it is to prevent the bacteria from the environment. The same is done at the end of milking (post-dipping), both of which can be done by dipping the udder in a detergent solution and then drying the surface.

Various of bacteria can be found in subclinical mastitis cases. Examination of bacterial samples of cow's milk with subclinical mastitis in KUNAK Bogor can be classified into 3 groups. According to Cowan \& Steels (2003) in their bacterial identification book, the first group is based on the characteristics of sthapylococcus sp (Figure $3 \mathrm{~A})$, second group is based the characteristics of the Streptococcus sp (Figure 3B), while third group is based on the characteristics of enterobacteria (Figure 3C). According to Taponen et al. (2009) microorganisms that cause inflammation in the udder include Staphylococcus aureus, Streptococcus uberis, Streptococcus dysgalactiae, Corynebacterium bovis, Staphilococcus aureus, Escherichia coli, Arcanobacterium pyogenes. Further more the study Bradley et al. (2007) found that Streptococcus uberis is present in many clinical and subclinical mastitis. However, Escherichia coli was present in the same amount as 
Streptococcus uberis in clinical mastitis. More identification needs to be conducted so that the treatment of subclinical mastitis can be performed optimally.

\section{ACKNOWLEDGMENT}

We thanks to staff of Microbiology Laboratorium in Eijkman Institute and all breeders in KUNAK Cibungbulang, Bogor.

\section{REFERENCES}

Akers, R.M. 2002. Lactation and the Mammary Gland. Ames: Iowa State University Press, US

Barnum DA, Newbould FHS. 1961. The Use of California Mastitis Test for the Detection of Bovine Mastitis. Can Vet Jour. 2(3): 83-90

Bewley J, Arnold M. 2012. Recomended Milking Procedures for Maximum Milk Quality. University of Kentucky, US

Blowey R, Edmondson P. 2010. Mastitis Control in Dairy Herds $2^{\text {nd }}$ Edition. London:CABI, UK

Bradley AJ, Leach KA, Breen JE, Green LE, Green MJ. 2007. Survey of the Incidence and Aetiology of Mastitis on Dairy Farms in England and Wales. Veterinary Record. 160:253-258

Cowan and Steels. 2003. Manual for the Identification of Medical Bacteria, third edition. UK:Cambridge University Press

Effendi MH. 2013. Angka Prevalensi Bovine Mastitis Beberapa Peternakan Sapi Perah di Jawa Timur [skripsi]. Surabaya:Universitas Airlangga

Harley JP, Prescott LM. 2002. Laboratory Exercise in Microbiology, fifth edition. USA: The McGraw-Hill Companies

Hidayat AP, Effendi AA, Fuad Y, Patyadi, Taguchi K, Sugiwaka T. 2002. Buku Petunjuk Teknologi Sapi Perah di Indonesia untuk Peternak: Kesehatan Pemerahan. Bandung:PT Sonysugema Pressindo, Indonesia
Jones GM. 2009. Understanding the Basics of Mastitis. Virginia: Virginia State University, US

Putri YS. 2012. Skrining dan Uji Aktivitas Enzim Protease Bakteri dari Limbah Rumah Pemotongan Hewan [skripsi]. Surabaya:Universitas Airlangga

Marlina. 2008. Identifikasi Bakteri Vibrio parahaemolitycus Dengan Metode Biolog Dan Deteksi Gen ToxR-nya Secara PCR. Jurnal Sains dan Teknologi Farmasi. 12 (1):11-17

Schroeder JW. 2012. Mastitis Control Programs: Bovine Mastitis and Milking Management. North Dakota:North Dakota State University, US

Seegers H, Fourichon C, Beaudeau F. 2003. Production Effects Related to Mastitis Economics in Dairy Cattle Herds. Vet Res, in press.

Sudarwanto, M. 1998. The IPB-I Reagent As An Alternative Tool To Detect Subclinical Mastitis. Media Veteriner, 5(1): 1-5

Surjowardojo P, Suyadi, Hakim L, Aulani'am. 2008. Ekspresi Produksi Susu pada Sapi Perah Mastitis. J. Ternak Tropika. 9 (2):1-11

Taponen S, Salmikivi L, Simojoki H, Koskinen MT, Pyörälä S. 2009. Real-time Polymerase Chain Reaction-based Identification of Bacteria in Milk Samples from Bovine Clinical Mastitis with no Growth in Conventional Culturing. J of Dairy Science. 26 (6):610-617

Zdanowicz M. 2002. Sand And Sawdust Bedding Affect Populations Of Coliforms, Klebsiella Spp. And Streptococcus Spp. On Teat Ends Of Dairy Cows Housed In Freestalls [thesis]. Colombia: University of British Columbia, Canada 